\title{
Implementasi Metode SQ3R dalam Upaya Peningkatan Kemampuan Membaca Pemahaman Pada Mata Pelajaran Bahasa Indonesia Siswa SDN 135 Rejang Lebong
}

\author{
Mawaria \\ SDN 135 Rejang Lebong \\ mawariahapiah@yahoo.com
}

\begin{abstract}
This research is motivated by problems in learning Indonesian. The view of reading is difficult to be embedded in students. The learning process carried out does not provide opportunities for students to develop ideas in developing the potential of reading skills. Classroom Action Research (CAR) consists of 2 cycles, each of which consists of two meetings. The stages in each cycle consist of the stages of planning, implementation, observation or observation, and reflection. The research subjects were fifth grade students of SDN 135 Rejang Lebong consisting of 23 people in the 2016/2017 school year. In the first cycle student learning outcomes obtained an average of 73.19 and the percentage of classical learning completeness was $69.56 \%$. In cycle II there were no more weaknesses that occurred in cycle I. Learning outcomes in the second cycle obtained an average of 81.69 with a percentage of classical learning completeness $91.30 \%$. This fulfills the completeness criteria, ie $85 \%$ of students get a value of ,07.0 and the learning process is said to be completed individually if students get a value of $\geq 7$.
\end{abstract}

Keywords: Reading Ability, SQ3R Method

Abstrak: Penelitian ini dilatarbelakangi problematika dalam pembelajaran bahasa Indonesia. Pandangan terhadap membaca itu sulit tertanam pada diri siswa. Proses pembelajaran yang dilakukan tidak memberikan kesempatan kepada siswa untuk mengembangkan ide dalam pengembangan potensi keterampilan dalam membaca. Penelitian Tindakan Kelas (PTK) ini terdiri dari 2 siklus, yang setiap siklusnya terdiri dari dua kali petemuan. Tahapan pada setiap siklus terdiri atas tahap perencanaan, pelaksanaan, pengamatan atau observasi, dan refleksi. Subjek penelitiannya adalah siswa kelas V SDN 135 Rejang Lebong yang terdiri dari 23 orang pada tahun pelajaran 2016/2017. Pada siklus I hasil belajar siswa diperoleh rata-rata 73,19 dan persentase ketuntasan belajar klasikal 69,56 \%. Pada siklus II tidak terdapat lagi

AR-RIAYAH : Jurnal Pendidikan Dasar vol. 2, no. 2, 2018

STAIN Curup - Bengkulu| pISSN2580-362X;e ISSN2580-3611

http://journal.staincurup.ac.id/index.php/JPD 
kelemahan-kelemahan yang terjadi pada siklus I. Hasil belajar pada siklus II diperoleh rata-rata 81,69 dengan persentase ketuntasan belajar klasikal $91,30 \%$. Hal ini memenuhi keriteria ketuntasan, yaitu $85 \%$ siswa memperoleh nilai $\geq 7,0$ dan proses pembelajaran dikatakan tuntas secara individu apabila siswa memperoleh nilai $\geq 7$.

Kata Kunci : Kemampuan Membaca, Metode SQ3R

\section{PENDAHULUAN}

Sekolah dasar sebagai jenjang pertama pendidikan, seharusnya dapat memberikan landasan yang kuat untuk tingkat selanjutnya. Tujuan pendidikan pada pendidikan dasar adalah memberikan bekal kemampuan dasar kepada peserta didik untuk mengembangkan kehidupannya sebagai pribadi, anggota masyarakat, warga negara dan anggota umat manusia serta mempersiapkan peserta didik untuk mengikuti pendidikan menengah. Dengan demikian sekolah dasar harus memberikan bekal kemampuan dan keterampilan dasar strategis sejak kelas-kelas awal.

Salah satu kemampuan dasar strategis itu adalah kemampuan dan keterampilan berbahasa. Dengan kemampuan berbahasa yang diperoleh sejak dini yang kemudian dikuasai, siswa dapat berkomunikasi antar sesamanya, menimba berbagai pengetahuan, serta mengembangkan diri secara berkelanjutan. Selain itu kemampuan dan keterampilan berbahasa tersebut sangat berguna dalam pembentukan pribadi menjadi warga negara, serta memahami dan berpartisipasi dalam pembangunan masyarakat atau bangsa.

Pada dasarnya, aspek pembelajaran bahasa Indonesia di SD mencakup empat aspek, yakni: (1) menyimak, (2) berbicara, (3) membaca, dan (4) menulis . Pengajaran bahasa Indonesia pada hakekatnya adalah pengajaran keterampilan berbahasa, bukan pengajaran tentang berbahasa. Keterampilan-keterampilan berbahasa yang perlu ditekankan dalam pengajaran berbahasa Indonesia adalah keterampilan reseptif (mendengarkan dan membaca) dan keterampilan produktif (menulis dan berbicara). Pengajaran berbahasa diawali dengan pengajaran keterampilan reseptif, sedangkan keterampilan produktif dapat turut ditingkatkan pada tahapan selanjutnya. Kemudian peningkatan kedua keterampilan tersebut akan menyatu sebagai kegiatan berbahasa yang terpadu.

${ }^{1}$ Puji santosa dkk,Materi dan pembelajaran Bahasa Indonesia di SD,(Universitas Terbuka: Jakarta,2010), 3.18 
Keempat keterampilan berbahasa adalah keterampilan menyimak, berbicara, membaca, dan menulis. Dengan cakupan pengetahuan semacam ini, pembelajaran secara tradisional sudah dianggap tidak cocok lagi. Dari keempat keterampilan tersebut salah satu keterampilan yang mempunyai peranan yang sangat penting adalah keterampilan membaca.

Pengajaran bahasa Indonesia menitikberatkan pada cara menggunakan bahasa untuk berkomunikasi. Dengan pengajaran bahasa Indonesia dapat dikembangkan keterampilan berbahasa siswa, khususnya siswa SD yang baru mengenal pembelajaran bahasa. Prestasi belajar yang baik merupakan komponen yang seharusnya dapat diwujudkan oleh setiap siswa. Untuk itu dalam proses pembelajaran seorang guru harus mampu melakukan berbagai usaha untuk dapat membantu siswa dalam proses pencapaian prestasi tersebut, yang kemudian diharapkan dapat memberikan suatu perubahan kemampuan kognitif, afektif dan psikomotorik pada diri siswa ke arah yang lebih baik.

Pentingnya keterampilan membaca di Sekolah Dasar ini perlu dikembangkan dengan sebuah metode yang dapat memberikan dampak positif dalam keberhasilan siswa dalam kemampuan bahasanya pada masa mendatang. Siswa tidak hanya memperoleh peningkatan dalam kemampuan bahasanya melainkan juga dalam kemampuan bernalar, kreativitas dan penghayatannya tentang nilai- nilai moral. Siswa tidak lagi hanya sekedar membaca saja melainkan siswa lebih dituntut untuk memahami isi bacaan. Apalagi dengan kemajuan zaman yang semakin lama semakin berkembang, informasi yang ada pun terus meningkat. Dengan situasi yang demikian tidak mungkin bagi siswa untuk menyerap informasi-informasi tersebut tanpa menggunakan metode yang tepat.

Pembelajaran yang selama ini sering dilaksanakan secara tradisional dengan hanya memberikan materi pelajaran yang berfokus pada pemberian konsepkonsep informasi dan fakta sebanyak-banyaknya kepada para siswa, sudah dianggap tidak tepat lagi. Dalam pembelajaran tersebut, hasil pelajaran yang diperoleh siswa pun terbatas pada pengetahuan dan memahami berbagai konsep, informasi, dan fakta tersebut, sedangkan aplikasinya belum tentu dapat dilakukan. Sementara itu, diketahui dalam pembelajaran bahasa Indonesia selain para siswa memahami konsep-konsep tentang ilmu bahasa, mereka juga harus mampu mengkomunikasikan kemampuannya sesuai dengan empat keterampilan berbahasa.

Berdasarkan hasil pengamatan di SDN 135 Rejang Lebong, diperoleh keterangan permasalahan dalam pembelajaran bahasa Indonesia khususnya 
pembelajaran keterampilan membaca, guru dan siswa mengatakan bahwa membaca itu sulit. Hal ini disebabkan, guru dalam melaksanakan pembelajaran membaca hanya menugaskan siswa membaca apa yang ada dalam buku tanpa memberikan kesempatan kepada siswa untuk mengembangkan ide atau gagasan yang dimiliki, misalnya guru menggunakan jenis membaca dalam hati kemudian siswa menjawab pertanyaan- pertanyaan di dalam teks bacaan kemudian didiskusikan dalam kelompok. Siswa tidak dituntut untuk lebih memahami teks bacaannya karena hanya sekedar membaca kemudian menjawab pertanyaan yang jawabannya ada di dalam teks bacaan kemudian dibacakan di depan kelas. Siswa umumnya sibuk sendiri, mengobrol dalam kelompok dan hanya beberapa siswa yang mengerjakan tugas dalam kelompoknya, bahkan ada yang terlihat bosan. Pada intinya guru kurang mampu menerapkan metode yang inovatif yang sesuai dengan kebutuhan siswa belajar bermakna. Selain itu diketahui bahwa hasil belajar siswa masih rendah yaitu dengan nilai rata- rata kelas 66,3. Hal ini belum memenuhi standar minimal yang diharapkan.

Sebagai solusi dari permasalahan di atas peneliti berdiskusi dengan guru kelas untuk melakukan perubahan terhadap metode pembelajaran dengan cara menerapkan metode yang memungkinkan siswa dapat menemukan sesuatu yang bermanfaat. Proses pembelajaran akan berjalan efektif, sehingga tujuan pembelajaran akan tercapai maksimal.

Penerapan metode SQ3R (Survey Question Read Recite Review) dan Pemberian Reward merupakan solusi yang dapat digunakan guru agar tidak adanya faktor membosankan dalam pembelajaran bahasa khususnya membaca. Membaca pemahaman dengan menerapkan metode SQ3R dan Pemberian Reward akan lebih efektif dibandingkan dengan metode membaca pemahaman lainnya, metode ini lebih menuntut siswa untuk menggali pemahaman mereka dengan lima tahapan proses membaca yang terdiri dari mensurvai isi, membuat pertanyaan, membaca isi, menceritakan isi bacaan dan meninjau kembali bacaan yang akan digabungkan dengan pemberian reward kepada siswa yang dapat menyelesaikan tugas dengan baik. Maka proses pembelajaran akan berlangsung dengan sangat menarik.sekaligus dalam satu kegiatan pembelajaran.

\section{LANDASAN TEORI}

\section{Pembelajaran Bahasa Indonesia}

Pengajaran Bahasa Indonesia menitik beratkan pada cara menggunakan bahasa untuk berkomunikasi. Dengan demikian pengajaran bahasa Indonesia 
tentunya harus dapat mengembangkan keterampilan berbahasa siswa yang meliputi: keterampilan menggunakan bahasa lisan, yaitu mendengarkan dan berbicara, dan keterampilan menggunakan bahasa tulis, yaitu untuk membaca dan menulis. Puji Santosa menjelaskan bahwa Pembelajaran Bahasa Indonesia di SD adalah proses memberi rangsangan belajar berbahasa kepada siswa dalam upaya siswa mencapai kemampuan berbahasa. ${ }^{2}$

Upaya-upaya yang dilakukan guru dapat berupa analisis tujuan dan karakteristik siswa, analisis sumber belajar, menetapkan strategi pengorganisasian, isi pembelajaran, menetapkan strategi penyampaian pembelajaran, menetapkan strategi pengelolaan pembelajaran, dan menetapkan prosedur pengukuran hasil pembelajaran. Oleh karena itu, setiap pengajar sebaiknya memiliki keterampilan dalam memilih strategi pembelajaran untuk setiap jenis kegiatan pembelajaran. Dengan demikian, pemilihan strategi pembelajaran yang tepat dalam setiap jenis kegiatan pembelajaran, diharapkan pencapaian tujuan belajar dapat terpenuhi. Oleh karena itu, pembelajaran bahasa diarahkan untuk meningkatkan kemampuan belajar dalam berkomunikasi, baik lisan maupun tulis.

\section{Hakikat Membaca Pemahaman}

Membaca merupakan kemampuan dan keterampilan untuk membuat suatu penafsiran terhadap bahan yang dibaca. Kepandaian membaca tidak hanya menginterpresentasikan huruf- huruf, gambar- gambar dan angka- angka saja, tetapi lebih luas daripada itu. Membaca yaitu kemampuan seseorang untuk dapat memahami makna dari sesuatu yang dibacanya, karena itulah membaca merupakan kegiatan intelektual yang dapat mendatangkan pandangan, sikap dan tindakan yang positif.

Membaca merupakan bagian terpadu dari kemampuan berbahasa. Membaca sangat bersandar pada kemampuan berbahasa. Pendekatan pengalaman berbahasa dapat digunakan dalam pengajaran membaca. Menurut pendekatan ini, kekuatan konseptual dan linguistik yang dibawa anak ke sekolah harus digunakan secara penuh.

Menurut Tarigan membaca adalah suatu proses yang dilakukan serta dipergunakan oleh pembaca untuk memperoleh pesan yang disampaikan oleh

${ }^{2}$ Puji santosa dkk, Materi dan Pembelajaran Bahasa Indonesia di SD,(Universitas Terbuka, 2010), 5.18 . 
penulis melalui media kata- kata bahasa tulis. ${ }^{3}$ Apabila dihubungkan dengan siswa di SD, berarti tujuan pembelajaran membaca adalah agar siswa memilki keterampilan berinteraksi dengan bahasa yang dialihkodekan dalam tulisan. Membaca hendaknya mempunyai tujuan, karena seseorang yang membaca dengan suatu tujuan, cenderung lebih memahami dibandingkan dengan orang yang tidak mempunyai tujuan. Dalam kegiatan membaca di kelas, guru seharusnya menyusun tujuan membaca dengan menyediakan tujuan khusus yang sesuai atau dengan membantu mereka menyusun tujuan membaca siswa itu sendiri.

Proses membaca adalah proses interaktif antara apa yang sudah diketahui seseorang (latar belakang pengetahuan) dengan unsur-unsur bacaaan, misalnya kata- kata yang digunakan, keteraturan dalam penulisan, pertautan antara satu konsep dengan konsep lainnya yang dipaparkan dengan jelas dalam tulisan dan sebagainya.

Proses membaca ini diarahkan oleh tujuan pemahaman isi bacaan. Bila tujuan membaca hanya mencari informasi khusus saja, proses yang terlibat tidak serumit apabila tujuan membacanya adalah belajar. Untuk mencapai tujuan belajar membaca, siswa harus dapat membaca dengan seksama, antara lain untuk menemukan tema bacaan, pikiran pokok dan penjelasan dalam bacaan, bagaimana hubungan antar informasi dalam bacaan.

Membaca pemahaman adalah suatu proses untuk mengenali atau mengidentifikasi teks, kemudian mengingat kembali isi teks. Membaca pemahaman juga dapat berarti sebagai suatu kegiatan membuat urutan tentang uraian/menggorganisasi isi teks, bisa mengevaluasi sekaligus dapat merespon apa yang tersurat atau tersirat dalam teks. Sedangkan pemahaman berhubungan laras dengan kecepatan. Pemahaman atau comprehension, adalah kemampuan membaca untuk mengerti: ide pokok, detail penting, dan seluruh pengertian. ${ }^{4}$ Membaca ini merupakan lanjutan dari membaca dalam hati tanpa suara dengan tujuan untuk memahami isi bacaan. ${ }^{5}$

Jadi kemampuan membaca pemahaman adalah kesanggupan atau kecakapan seseorang untuk memahami isi suatu bacaan. Pemahaman isi bacaan

\footnotetext{
${ }^{3}$ Hadisusanto,MembacaPemahaman,https://bagawanabiyasa.wordpress.com/2015/12/0 3/membaca-pemahaman/ di akses pada Tanggal 12 April 2017 pukul 23.00

${ }^{4}$ Hadisusanto,MembacaPemahaman,https://bagawanabiyasa.wordpress.com/2015/12/0 3/membaca-pemahaman/Tgl 12 April 2017 pukul 23.00

${ }^{5}$ Puji santosa dkk,Materi dan Pembelajaran Bahasa Indonesia di SD,Universitas Terbuka,2010,hlm 3.20
} 
itu sendiri disesuaikan dengan tujuan atau aspek-aspek kemampuan atau keterampilan intelektual yang ada dalam membaca pemahaman itu sendiri.

\section{Metode SQ3R}

Metode SQ3R merupakan suatu prosedur belajar yang sistematik dan bersifat praktik. Metode SQ3R merupakan suatu metode membaca yang sangat baik untuk kepentingan membaca secara intensif dan rasional. Robinson (dalam Hanafiah) menyatakan tentang Effective Study, melalui kegiatan membaca dengan metode SQ3R, yaitu: (1) Survey, yaitu menyelidiki terlebih dahulu untuk mendapat gambaran selintas mengenai isi/pokok yang akan dipelajari; (2) Question, yaitu mengajukan pertanyaan dari ide pokok atau isi buku yang dibaca secara selintas (3) Read, yaitu membaca secara aktif untuk memberikan jawaban terhadap pertanyaan yang dibuat; (4) Recite, yaitu mengucapkan kembali atas jawaban yang diberikan terhadap pertanyaan dengan tidak melihat buku/menengok terhadap catatan kecil yang menjadi garis besar; (5) Review, yaitu mengulang apa yang dibacanya dengan memeriksa kertas catatannya. ${ }^{6}$

\section{Pengertian Reward}

Penguatan adalah respon terhadap suatu perilaku yang dapat meningkatkan kemungkinan berulangnya kembali perilaku itu. Dalam rangka pengelolaan kelas, dikenal penguatan positif dan penguatan negatif. Penguatan positif adalah penguatan yang bertujuan untuk mempertahankan dan memelihara perilaku positif, sedangkan penguatan negatif merupakan penguatan perilaku dengan cara menghentikan atau menghapus rangsangan yang tidak menyenangkan. Misalnya dalam penguatan negatif, guru memberikan sindiran kepada siswa yang tidak memperhatikan saat guru tersebut menerangkan suatu materi pelajaran. ${ }^{7}$

Reward pada dasarnya dapat diberikan dalam dua jenis yaitu verbal dan non verbal Secara rinci, komponen- komponen keterampilan tersebut adalah sebagai berikut:

\section{Verbal}

\footnotetext{
http://globallavebookx.blogspot.co.id/2015/02/pengertian-dan-manfaat-metodesq3r.html. 24 maret 2017

${ }^{7}$ Khoirunnisa dkk, Makalah, https://areknerut.wordpress.com/2012/12/30/keterampilan-memberikan-penguatan-dalamproses-pembelajaran/(online) diakses tgl 25 april 2017
} 
Reward verbal paling mudah digunakan dalam kegiatan pembelajaran dalam bentuk komentar, pujian, dukungan, pengakuan atau dorongan yang diharapkan dapat meningkatkan tingkah laku dan penampilan siswa.

\section{Non verbal}

Penguatan nonverbal dapat ditunjukkan dengan berbagai cara, antara lain; (a) Mimik dan gerakan badan; (b) Gerak mendekati; (c) Sentuhan; (d) Kegiatan yang menyenangkan; (e) Pemberian simbol atau benda; (f) Penguatan tak penuh. Agar reward yang diberikan dapat berfungsi secara efektif, hendaknya memperhatikan prinsip- prinsip pemberian reward seperti sebagai berikut; (a) Kehangatan dan keantusiasan; (b) Kebermaknaan; dan (c) Menghindari penggunaan respon negatif.

\section{Hasil Belajar}

Benyamin Bloon menyatakan bahwa hasil belajar yang sering digunakan berupa kemampuan siswa dalam menguasai materi yang dilihat dari tes belajar siswa. Hasil belajar tersebut dibagi menjadi tiga ranah yaitu: (a) ranah kognitif yang berkenaan dengan hasil belajar intelektual yang terdiri dari enam aspek, yakni pengetahuan atau ingatan, pemahaman, aplikasi, analisis, sintesis, evaluasi, (b) ranah afektif yang berkenaan dengan sikap yang terdiri dari lima aspek yakni penerimaan, jawaban atau reaksi, penilaian, organisasi, dan internalisasi, (c) ranah psikomotorik yang berkenaan dengan hasil belajar keterampilan dan kemampuan bertindak. $^{8}$

\section{METODE PENELITIAN}

Jenis penelitian ini adalah Penelitian Tindakan Kelas (Classroom Action Research). PTK merupakan jenis penelitian yang bertujuan untuk peningkatan pembelajaran melalui serangkaian tindakan yang diikuti dengan refleksi. Kemudian mencobakan dan mempraktekan secara sistematis mengenai permasalahan di dalam kelas secara reflektif dan berpenerapan guna meningkatkan kualitas pembelajaran dan hasil belajar siswa.

Penelitian ini dilaksanakan di ruang kelas dengan menggunakan beberapa siklus. Setiap siklusnya terdiri atas beberapa tahapan yaitu: (1) Perencanaan

8 Rijal 09.Pengertian hasil belajar, http://www.rijal09.com/2016/03/pengertian-hasilbelajar.html,diakses tanggal 12 april 2017. 
(planning); (2) Pelaksanaan tindakan (action); (3) Pengamatan (observation); dan (4) Refleksi (reflection).?

Teknik analisis data akan fokus kepada analisis data observasi dan analisis hasil belajar. Data diolah dengan menganalisis semua hasil penelitian yang diperoleh dari tindakan pertama dan kedua yang termuat dalam lembar observasi pada aspek keaktifan siswa dengan menerapkan teknik persentase. Data hasil observasi dengan menggunakan lembar observasi guru dan siswa untuk setiap aspek yang diamati. Kategori yang digunakan adalah kurang $(\mathrm{K})$, cukup $(\mathrm{C})$, dan baik (B). ${ }^{10}$ Data observasi yang diperoleh digunakan untuk merefleksi tindakan yang telah dilakukan dan diolah secara deskriptif dengan menghitung:
a. Rata-rata skor $=\frac{\text { Jumlah skor }}{\text { Jumlah observer }}$
b. Skor Tertinggi = Jumlah aspek yang diamati $\mathrm{x}$ Skor tertinggi tiap butir observasi
c. Skor terendah = Jumlah aspek yang diamati $\mathrm{x}$ skor terendah tiap butir observasi
d. Selisih skor = Skor tertinggi - skor terendah

\section{Kisaran nilai untuk tiap kriteria $=\frac{\text { Selisih Skor }}{\text { Jumlah kriteria penilaian }}$}

Sedangkan untuk analisis belajar akan menggunakan rumus untuk menghitung rata-rata skor dan persentasi hasil analisis sebagai berikut:

$\mathrm{X}=\frac{\sum X}{N}$

Keterangan :

$\mathrm{X} \quad=$ Rata-rata skor yang dicari

$\sum \mathrm{X}=$ Jumlah skor

$\mathrm{N} \quad=$ Jumlah siswa

Persentase ketuntasan belajar secara klasikal

9 IGAK Wardhani dkk,Penelitian Tindakan Kelas, (Universitas Terbuka,Jakarta,2007), 10 Nana Sudjana.., 27 
$\mathrm{KB}=\frac{N S}{N} X 100 \%$

Keterangan :

$\mathrm{KB}=$ Ketuntasan Belajar Klasikal

NS = Jumlah Siswa yang mendapat Nilai $\geq 75$

$\mathrm{N} \quad=$ Jumlah siswa

\section{HASIL PENELITIAN}

Berdasarkan hasil pengamatan di SDN 135 Rejang Lebong, diperoleh keterangan permasalahan dalam pembelajaran bahasa Indonesia khususnya pembelajaran keterampilan membaca, guru dan siswa mengatakan bahwa membaca itu sulit. Hal ini disebabkan, guru dalam melaksanakan pembelajaran membaca hanya menugaskan siswa membaca apa yang ada dalam buku tanpa memberikan kesempatan kepada siswa untuk mengembangkan ide atau gagasan yang dimiliki, misalnya guru menggunakan jenis membaca dalam hati kemudian siswa menjawab pertanyaan- pertanyaan di dalam teks bacaan kemudian didiskusikan dalam kelompok. Siswa tidak dituntut untuk lebih memahami teks bacaannya karena hanya sekedar membaca kemudian menjawab pertanyaan yang jawabannya ada di dalam teks bacaan kemudian dibacakan di depan kelas. Siswa umumnya sibuk sendiri, mengobrol dalam kelompok dan hanya beberapa siswa yang mengerjakan tugas dalam kelompoknya, bahkan ada yang terlihat bosan. Pada intinya guru kurang mampu menerapkan metode yang inovatif yang sesuai dengan kebutuhan siswa belajar bermakna.

\section{SIKLUS I}

Tabel Hasil Analisis Data Observasi Siswa Siklus I

\begin{tabular}{llll}
\hline No & Pengamat & Pertemuan ke-1 & Pertemuan ke-2 \\
\hline 1 & 1 & 23 & 25 \\
\hline 2 & 2 & 25 & 26 \\
\hline \multicolumn{2}{l}{ Jumlah } & 48 & 51 \\
\hline \multicolumn{2}{l}{ Rata-rata } & 24 & 25,5 \\
\hline
\end{tabular}




\begin{tabular}{ll}
\hline Nilai akhir rata-rata & 24,75 \\
\hline Kriteria Penilaian & Cukup \\
\hline
\end{tabular}

Berdasarkan tabel di atas, diperoleh keterangan bahwa rata-rata skor observasi siswa adalah 24,5 dengan kriteria cukup. Dalam pelaksanaan siklus I ditemukan kelemahan-kelemahan pada saat proses pembelajaran, yaitu:

a. Ada beberapa siswa yang belum memahami langkah kerja LKS.

b. Hanya beberapa siswa saja yang aktif dalam proses pembelajaran khususnya menceritakan kembali teks bacaan ke depan kelas.

c. Sedikit sekali siswa yang aktif bertanya kepada guru.

d. Siswa kurang memahami langkah $S Q 3 R$.

Tes yang dilaksanakan pada siklus I yaitu berupa pengerjaan Lembar Kerja Siswa (LKS) pada proses pembelajaran yang disesuaikan dengan langkahlangkah $S$ Q3R dan tujuan pembelajaran yang ingin dicapai. Berdasarkan hasil tes kemudian dianalisis dengan kriteria persentase ketuntasan belajar klasikal siswa. Dari analisis hasil belajar siklus I menunjukkan bahwa pembelajaran membaca pemahaman dengan menerapkan metode $S Q 3 R$ dan pemberian reward pada siklus I belum dinyatakan tuntas secara klasikal, yaitu dengan perolehan nilai rata-rata 73,19 dari 23 siswa siswa yang mendapat nilai $\geq 75$ adalah 16 orang atau 69,56\%. Ini menunjukkan bahwa proses pembelajaran yang telah dilakukan pada siklus I belum tuntas. Ketidaktuntasan hasil belajar ini dikarenakan proses pembelajaran bahasa Indonesia dengan menerapkan metode SQ3R dan pemberian reward belum terlaksanakan dengan baik karena adanya kekurangan dan kelemahan pada pelaksanaan tindakan, baik aktivitas guru maupun aktivitas siswa. Dengan demikian diperlukan refleksi untuk proses kegiatan pembelajaran selanjutnya. 
188 | AR-RIAYAH : Jurnal Pendidikan Dasar vol. 2, no. 2, 2018

\section{SIKLUS II}

Tabel Hasil Analisis Data Observasi Siswa Siklus I

\begin{tabular}{llll}
\hline No & Pengamat & Pertemuan-1 & Pertemuan-2 \\
\hline 1 & 1 & 33 & 34 \\
\hline 2 & 2 & 35 & 36 \\
\hline Jumlah & 68 & 70 \\
\hline \multicolumn{2}{l}{ Rata-rata } & 34 & 35 \\
\hline Nilai akhir rata-rata & 34,5 & \\
\hline Kriteria Penilaian & Baik \\
\hline
\end{tabular}

Berdasarkan tabel di atas menunjukkan bahwa aktivitas siswa pada proses pembelajaran rata-rata skor yang diperoleh dari dua orang pengamat sebesar 34,5. Nilai ini termasuk dalam kategori baik. Kegiatan pembelajaran dengan menggunakan metode SQ3R dan pemberian reward pada siklus II ini telah mengalami peningkatan dari proses pembelajaran pada siklus I.

\section{PEMBAHASAN}

Berdasarkan hasil analisis data, dapat diketahui bahwa penerapan metode SQ3R dan pemberian reward dapat meningkatkan aktivitas dan hasil belajar siswa dalam proses pembelajaran. Hal ini dapat terjadi karena metode $S Q 3 R$ menurut Leo (1994:5) bahwa SQ3R ternyata dapat memperbaiki pemahaman, ingatan siswa terhadap teks bacaan. Bahkan metode ini lebih efektif dan lebih efisien dalam kegiatan membaca untuk studi. metode SQ3R yang sudah dituangkan dalam teknik-teknik $S Q 3 R$ dinilai sangat efektif untuk tujuan pemerolehan informasi dalam rangka peningkatan hasil belajar dan untuk tujuan kerja. Dan pemberian reward sendiri terbukti dapat meningkatkan motivasi belajar siswa, sehingga mengakibatkan aktivitas siswa dan hasil belajar siswa meningkat.

Hasil penelitian dengan penerapan metode SQ3R dan pemberian reward dari kegiatan pra siklus sampai pada kegiatan siklus II menunjukkan bahwa adanya peningkatan yang tinggi dalam hal proses (meliputi aktivitas guru dan siswa) dan hasil belajar. Hal ini menunjukkan bahwa penerapan metode SQ3R 
dan pemberian reward sangat berpengaruh dalam meningkatkan proses dan hasil belajar siswa dalam memahami isi bacaan pada pembelajaran bahasa Indonesia.

Berdasarkan hasil pengamatan kolaboratif pada kegiatan pembelajaran dengan penerapan metode $S Q 3 R$ dan pemberian reward yang telah dilaksanakan dalam 2 siklus dimana setiap siklus terdiri atas 2 pertemuan diperoleh gambaran bahwa kemampuan guru dalam melaksanakan proses pembelajaran telah meningkat. Hal ini disebabkan karena guru telah terbiasa melakukan kegiatan secara bertahap. Berdasarkan analisis data yang dilakukan terhadap lembar aktivitas guru yang diamati oleh dua orang pengamat tampak bahwa terjadi peningkatan rata-rata aktivitas guru dalam pelaksanaan pembelajaran pada saat siklus I, dan siklus II. Hal tersebut dapat dilihat dalam tabel perbandingan hasil aktivitas guru pada siklus I dan siklus II dibawah ini.

Tabel Perbandingan Hasil Observasi Aktivitas Guru Siklus I dan Siklus II

\begin{tabular}{lll}
\hline & \multicolumn{2}{l}{ Skor Aktivitas Guru } \\
\cline { 2 - 3 } & Siklus I & Siklus II \\
\hline Pertemuan 1 & 24 & 33,5 \\
\hline Pertemuan 2 & 25,5 & 35 \\
\hline Rata-rata skor & 24,75 & 34,25 \\
\hline
\end{tabular}

Berdasarkan tabel perbandingan hasil observasi aktivitas guru di atas dalam pembelajaran benar-benar menunjukkan cukup besar peranan guru sebagai fasilitator dan motivator secara optimal. Hal ini dapat dilihat pada siklus I ratarata skornya 24,75 termasuk dalam kategori cukup meningkat menjadi 34,25 termasuk dalam kategori baik pada siklus II.

Penerapan metode $S Q 3 R$ dan pemberian reward pada siswa Kelas V SDN 135 Rejang Lebongyang dilakukan oleh guru adalah memberikan pembelajaran yang berpusat kepada siswa (student centered), hal ini terlihat dari siswa banyak ditempatkan sebagai subjek belajar sedangkan guru berperan sebagai fasilitator yang memberikan kemudahan-kemudahan kepada siswa untuk melakukan aktivitas belajar. Guru lebih banyak membimbing siswa dengan memberikan pertanyaan-pertanyaan untuk mempermudah siswa menemukan sendiri konsep- 
konsep yang dipelajari. Pertanyaan-pertanyaan yang diberikan bertujuan untuk memotivasi siswa untuk aktif dalam kegiatan pembelajaran.

Pembelajaran yang berpusat pada siswa dengan penerapan metode $S Q^{3 R}$ dan pemberian reward memberikan kebermaknaan bagi murid karena dapat memahami bacaan dengan menerapkan langkah-langkah SQ3R secara sistematis. Serta siswa akan selalu termotivasi dengan reward yang diberikan oleh guru baik secara verbal maupun non verbal. Hal ini terlihat pada jumlah rata-rata skor yang diperoleh pada lembar aktivitas siswa yang mengalami peningkatan dari siklus I dan siklus II di bawah ini :

Tabel Perbandingan Hasil Observasi

Aktivitas Siswa Siklus I dan Siklus II

\begin{tabular}{|c|c|c|}
\hline & \multicolumn{2}{|c|}{ Skor Aktivitas Siswa } \\
\hline & Siklus I & Siklus II \\
\hline Pertemuan I & 24 & 34 \\
\hline Pertemuan II & 25,5 & 35 \\
\hline Rata-rata skor & 24,5 & 34,5 \\
\hline
\end{tabular}

Dari tabel tersebut terjadi peningkatan pada siklus II, hal ini terlihat dari perolehan skor pada saat siklus I rata-rata jumlah skor 24,5 dengan kriteria cukup meningkat menjadi 34,5 pada siklus II dengan kriteria baik. Dengan demikian dapat dikatakan bahwa proses pembelajaran dengan penerapan metode SQ3R dan pemberian reward sudah berjalan dengan baik dari segi aktivitas guru maupun aktivitas siswa di dalam pembelajaran. Dengan meningkatnya kualitas pembelajaran baik dari segi aktivitas guru dan dari segi aktivitas siswa menyebabkan pembelajaran menjadi lebih baik dan meningkatnya prestasi belajar siswa.

Dengan meningkatnya kualitas proses pembelajaran yang dilakukan oleh guru dan siswa maka hasil belajar pun menjadi meningkat. Berdasarkan hasil penelitian yang dilaksanakan pada siswa Kelas $V$ yang berjumlah 23 orang di SDN 135 Rejang Lebong, diperoleh bahwa persentase ketuntasan belajar siswa meningkat dari siklus I dan siklus II. Hal tersebut dapat dilihat pada tabel 
perbandingan persentase ketuntasan belajar klasikal yang diperoleh pada saat siklus I dan siklus II.

Tabel Perbandingan Nilai Rata-rata dan Persentase Ketuntasan Belajar Klasikal dari Pra siklus, Siklus I, dan siklus II

\begin{tabular}{lll}
\hline Siklus & Nilai rata-rata & Ketuntasan Belajar \\
\hline Siklus I & 73,19 & $69,56 \%$ \\
\hline Siklus II & 81,69 & $91,30 \%$ \\
\hline
\end{tabular}

Hasil belajar juga menunjukkan peningkatan yang signifikan dari siklus I hingga siklus II yaitu nilai rata-rata siswa dari 73,19 dan meningkat lagi pada siklus II menjadi 81,69 demikian juga dengan ketuntasan belajar klasikal dari 69,56 \% meningkat lagi menjadi $91,30 \%$ pada siklus II. Hal ini menunjukkan bahwa hasil belajar pada siklus II telah dikategorikan belajar tuntas karena dari 23 orang siswa yang mendapat nilai $\geq 75$ ke atas sebanyak 21 orang atau 91,30\%. Hasil yang dicapai dalam siklus II sudah sesuai dengan acuan menurut Nurgiantoro kriteria ideal ketuntasan belajar untuk masing-masing indikator $75 \%$ dan untuk mata pelajaran Bahasa Indonesia indikator ketuntasan belajar secara klasikal apabila siswa di kelas memperoleh nilai $\geq 75$ ke atas sebanyak $75 \%$

Berdasarkan hal tersebut bahwa metode $S Q^{3 R}$ dan pemberian reward dapat meningkatkan kualitas proses dan hasil belajar siswa. Dipilihnya metode SQ3R dan pemberian reward ini karena metode ini memiliki penilaian masingmasing pada proses pembelajaran yang saling berkaitan. Penilaian itu dilakukan pada saat proses pembelajaran berlangsung. Sehigga guru bisa menilai secara langsung bagaimana keaktivan siswa dalam proses pembelajaran.

Meski terkesan sangat mekanistik, tetapi membaca dengan menggunakan SQ3R dianggap lebih memuaskan karena dengan teknik ini dapat mendorong siswa untuk lebih memahami apa yang dibacanya, terarah pada intisari atau kandungan- kandungan pokok yang tersirat dan tersurat dalam suatu buku atau teks. Selain itu, langkah-langkah yang ditempuh dalam teknik ini tampaknya sudah menggambarkan prosedur ilmiah, sehingga diharapkan diharapkan setiap informasi yang dipelajari dapat tersimpan dengan baik dalam sistem memori jangka panjang siswa. 


\section{KESIMPULAN}

Aktivitas belajar guru dan siswa dapat meningkat dengan penerapan metode $S Q 3 R$ dan pemberian reward pada pembelajaran membaca di kelas $\mathrm{V}$ SDN 135 Rejang Lebong. Hal ini dapat dilihat dari rata-rata skor aktivitas guru siklus I mendapat skor 24,75, meningkat pada siklus II dengan skor 34,25. Begitu pun dengan rata-rata skor aktivitas siswa siklus I mendapatkan skor 24,5 meningkat pada siklus II dengan skor 34,5. Dimana rata-rata skor untuk siklus I mendapat kriteria "cukup" dan siklus II mendapat kriteria "baik". Kemampuan memahami isi bacaan siswa dapat meningkat dengan metode SQ3R dan pemberian reward pada pembelajaran membaca di kelas V SDN 135 Rejang Lebong. Hal ini dapat lihat pada nilai rata-rata siswa memperoleh nilai 73,19 dengan persentase ketuntasan klasikal 69,56 \% meningkat pada siklus II dengan perolehan skor rata-rata 81,69 dengan persentase ketuntasan klasikal 91,30 \% .

\section{DAFTAR PUSTAKA}

Santosa, Puji, dkk. 2005. Materi dan Pembelajaran Bahasa Indonesia SD. Jakarta: Universitas Terbuka.

Wardani, dkk. 2004. Penelitian Tindakan Kelas. Jakarta: Universitas Terbuka.

Hadisusanto,MembacaPemahaman,https://bagawanabiyasa.wordpress.com/20 15/12/03/membaca-pemahaman

http:/ /globallavebookx.blogspot.co.id/2015/02/pengertian-dan-manfaatmetode-sq3r

Khoirunnisadkk,Makalah,https://areknerut.wordpress.com/2012/12/30/keter ampilan-memberikan-penguatan-dalam-proses-pembelajaran/(online)

Rijal 09.Pengertian hasil belajar, http://www.rijal09.com/2016/03/pengertianhasil-belajar 